\title{
Simulators as Hydraulic Test Facilities at Dikes and other Coastal Structures
}

\author{
Gosse Jan Steendam Infram BV, Marknesse, The Netherlands \\ Jentsje van der Meer Van der Meer Consulting BV, Akkrum, The Netherlands \\ Paul van Steeg Deltares, Delft, The Netherlands \\ André van Hoven Deltares, Delft, The Netherlands \\ Gerben van der Meer Van der Meer Innovations, Broek-Noord, The Netherlands
}

\section{Summary}

The first part of this paper gives a short description of wave processes on a dike, on what we know, including recent new knowledge. These wave processes are wave impacts, wave run-up and wave overtopping. The second part focuses on description of three Simulators, each of them simulating one of the wave processes and which have been and are being used to test the strength of grass covers on a dike under severe storm conditions.

\section{Introduction}

When incident waves reach a coastal structure such as dike or levee, they will break if the slope is fairly gentle. This may cause impacts on the slope in zone 2, see Figure 1. When large waves attack such a dike the seaward side in this area will often be protected by a placed block revetment or asphalt. The reason is simple: grass covers cannot withstand large wave impacts, unless the slope is very mild.

Above the impact zone the wave runs up the slope and then rushes down the slope till it meets the next up-rushing wave. This is the run-up and run-down zone on the seaward slope (zone 3 in Figure 1). Uprushing waves that reach the crest will overtop the structure and the flow is only to one side: down the landward slope, see zone's 4 and 5 in Figure 1.

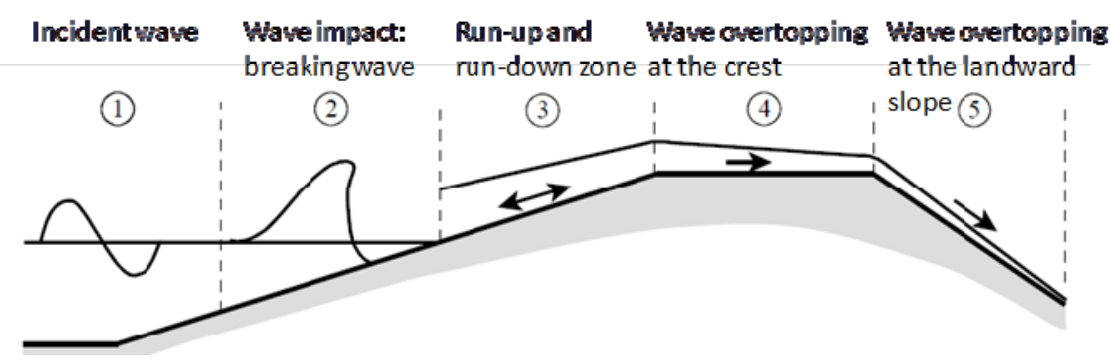

Figure 1. Process of wave breaking, run-up and overtopping at a dike (figure partly from Schüttrumpf (2001)).

Design of coastal structures is often focussed on design values for certain parameters, like the $p_{\max , 2 \%}$ or $\mathrm{p}_{\max }$ for a design impact pressure, $\mathrm{Ru}_{2 \%}$ for a wave run-up level and $\mathrm{q}$ as mean overtopping discharge or $\mathrm{V}_{\max }$ as maximum overtopping volume. A structure can then be designed using the proper partial safety factors, or with a full probabilistic approach. For wave flumes and wave basins, the waves and the wave processes during wave-structure interaction are simulated correctly using a Froude scale and it are these facilities that have provided the design formulae for the parameters described above. 
Whether the strength of coastal structures can also be modelled on small scale depends on the structure considered. The erosion of grass on clay cannot be modelled on a smaller scale and one can only perform resistance testing on real dikes, or on parts moved to a large-scale facility as the Delta Flume of Deltares or the GWK in Hannover, Germany. Resistance testing on real dikes can also be performed by the use of Simulators, which is the subject of this paper. Each Simulator has been developed to simulate only one of the processes in Figure 1 and for this reason three different types of simulator are available today.

If one wants to simulate one of these processes at a real dike, without a wave flume or wave basin, one first has to describe and model the process that should be simulated. Description of the wave structure interaction process is, however, much more difficult than just the determination of a design value. The whole process for each wave should be described as good as possible.

\section{Simulation of wave structure interaction processes General aspects}

Three different wave-structure-interaction processes are being recognized on a sloping dike, each with design parameters, but also with other parameters which have to be described for all waves. An overall view is given below.
Impacts:
Design parameters: $\quad \mathrm{p}_{\max , 2 \%} ; \mathrm{p}_{\max }$
Description of process: distribution of impact pressures, rise times,
Wave run-up and run-down: impact durations, impact width $\left(B_{\text {impact }, 50 \%}\right)$ and impact locations;
Design parameters: $\quad \mathrm{Ru}_{2 \%} ; \mathrm{Rd}_{2} \%$
Description of process: distributions of run-up and run-down levels, velocities along the slope for each wave;
Wave overtopping:
Design parameters: $\quad \mathrm{q} ; \mathrm{V}_{\max }$
Description of process: distributions of individual overtopping volumes, flow velocities, thicknesses and overtopping durations.

\section{Wave impacts}

A lot of information on wave impacts has been gathered for the design of placed block revetments on sloping dikes. Klein Breteler (2012) gives a full description of wave impacts and a short summary of the most important parameters is given here. Wave impacts depend largely on the significant wave height. For grassed slopes on a dike the wave impact is often limited, say smaller than $H_{s}=1 \mathrm{~m}$, otherwise the slope would not be able to resist the impacts. Tests from the Delta Flume with a wave height of about $0.75 \mathrm{~m}$ have been used to describe the process of wave impacts. The $2 \%$-value of the maximum pressure can be described by (Klein Breteler (2012):

$$
\begin{aligned}
& \left(\frac{p_{\max , 2 \%}}{\gamma_{\text {berm, } p_{\max } H_{s}}}\right)\left(\frac{\rho_{w} g H_{S}^{2}}{\sigma_{w}}\right)^{0.1}=12-0.28 \frac{\xi_{o p}}{\tan \alpha_{T}} \text { for } 3 \leq \frac{\xi_{o p}}{\tan \alpha_{T}} \leq 24 \\
& \text { with } \left.\gamma_{\text {berm, } p_{\text {max }}}=0.17\left(\frac{h_{b}}{H_{s}}-1.2\right)\right)^{2}+1
\end{aligned}
$$

where:

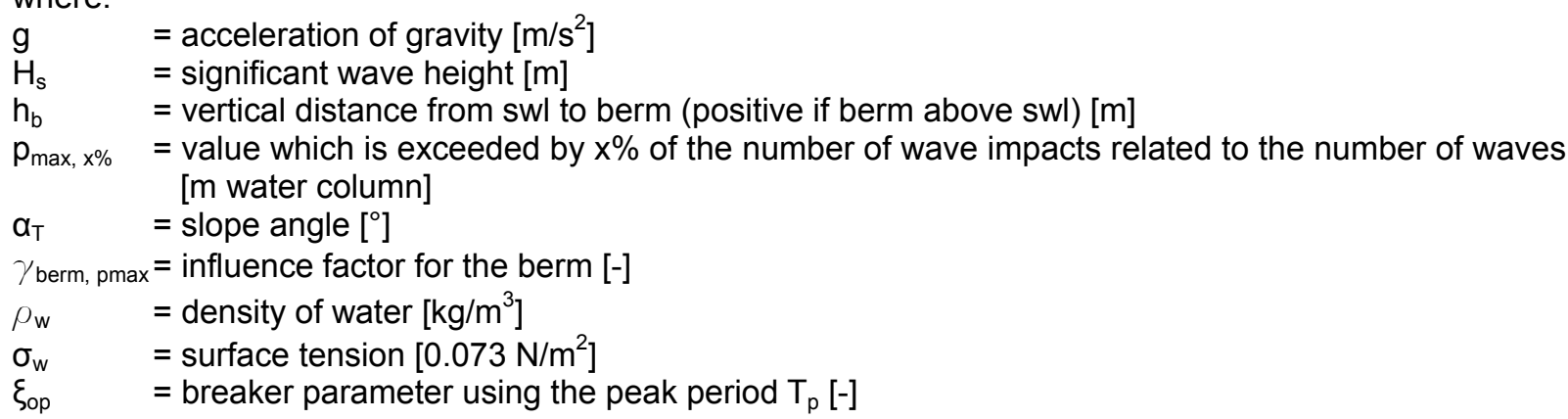


The tests in the Delta Flume clearly showed that the distribution of $p$ is Rayleigh distributed, see Figure 2. The graph has the horizontal axis according to a Rayleigh distribution and a more or less straight line then indicates a Rayleigh distribution. This is indeed the case in Figure 2.

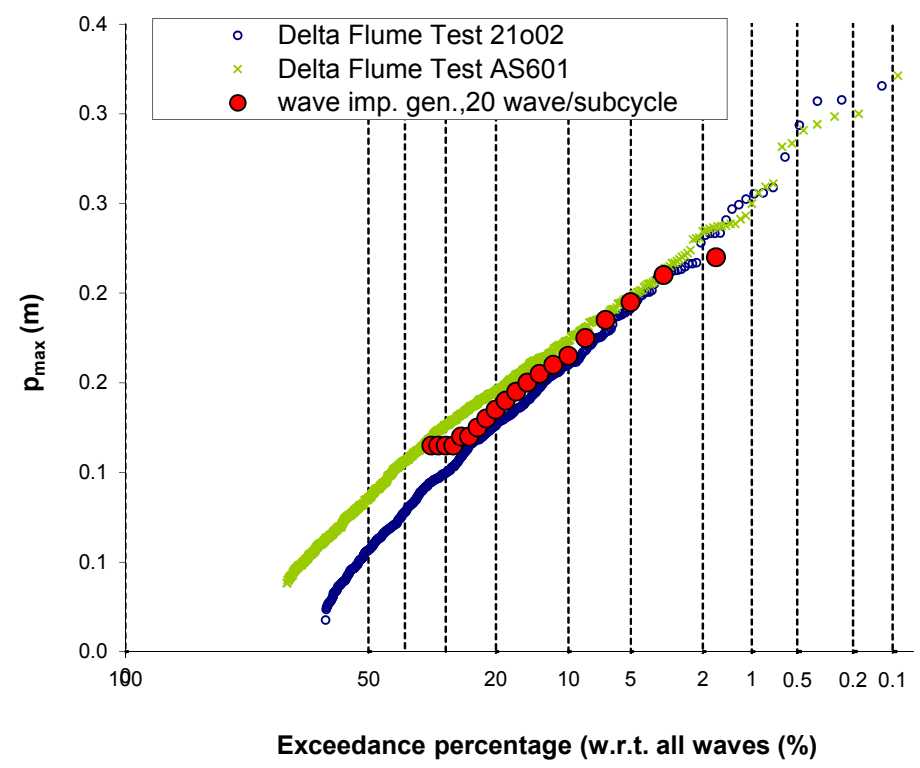

Figure 2. Peak pressures of impacts, measured in the Delta Flume and given on Rayleigh paper. Also simulated pressures are shown (described later in the paper)

Each parameter can be given as a distribution or exceedance curve, but often the relationship between two parameters is not so straight forward. Figure 3 shows the relationship between the peak pressure and the corresponding width of the impact, $\mathrm{B}_{\text {impact, } 50 \%}$ for a wave field with $\mathrm{H}_{\mathrm{s}} \approx 0.75 \mathrm{~m}$. It shows that peak pressures may give values between 0.25 and $3 \mathrm{~m}$ water column, whereas the width of impact may be between 0.15 and $1 \mathrm{~m}$, with an average value around $0.4 \mathrm{~m}$. But there is hardly any correlation between both parameters.

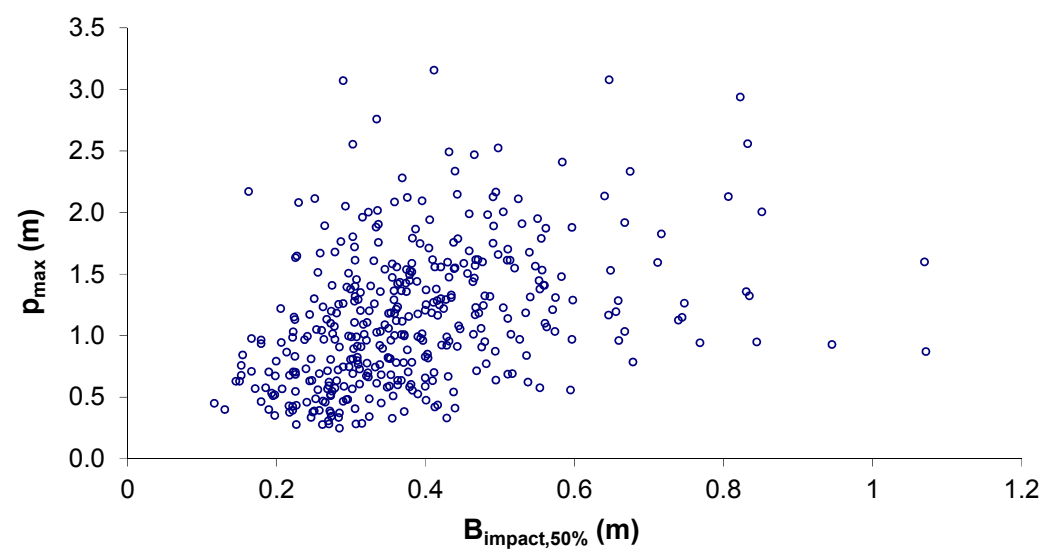

Figure 3. Peak pressures of impacts versus the width of the impacts (Delta flume measurements, Klein Breteler, 2012)

\section{Wave run-up and run-down}

The engineering design parameter for wave run-up is the level on the slope that is exceeded by $2 \%$ of the up-rushing waves $\left(\mathrm{Ru}_{2 \%}\right)$. The EurOtop Manual (2007) gives methods to calculate the overtopping 
discharge as well as the $2 \%$ run-up level for all kinds of wave conditions and for many types of coastal structures. Knowing the $2 \%$ run-up level for a certain condition is the starting point to describe the wave run-up process. Assuming a Rayleigh distribution of the run-up levels and knowing $\mathrm{Ru}_{2 \%}$ gives all the required run-up levels. As the EurOtop Manual (2007) is readily available, formulae for wave run-up have not been repeated here.

The wave run-up level is a start, but also run-up velocities and flow thicknesses are required. From the wave overtopping tests it is known that the front velocity is the governing parameter in initiating damage to a grassed slope. Focus should therefore be on describing this front velocity along the upper slope. By only considering random waves and the $2 \%$-values, the equations for run-up velocity and flow thickness become:

$$
\begin{aligned}
& u_{2 \%}=c_{u 2 \%}\left(g\left(R u_{2 \%}-z_{A}\right)\right)^{0.5} \\
& h_{2 \%}=c_{h 2 \%}\left(R u_{2 \%}-z_{A}\right)
\end{aligned}
$$

where:

$\mathrm{U}_{2 \%} \quad$ = run-up velocity exceeded by $2 \%$ of the up-rushing waves

$\mathrm{C}_{\mathrm{u} 2 \%} \quad=$ coefficient

$\mathrm{g} \quad=$ acceleration of gravity

$\mathrm{Ru}_{2 \%} \quad=$ maximum level of wave run-up related to the still water level swl

$\mathrm{Z}_{\mathrm{A}} \quad=$ location on the seaward slope, in the run-up zone, related to swl

$\mathrm{h}_{2 \%} \quad$ = flow thickness exceeded by $2 \%$ of the up-rushing waves

$\mathrm{C}_{\mathrm{h} 2 \%} \quad$ coefficient

The main issue is to find the correct values of $\mathrm{c}_{\mathrm{u} 2 \%}$ and $\mathrm{c}_{\mathrm{h} 2 \%}$. But comparing the results of various research studies (see Van der Meer et al. (2012)) gives the conclusion that they are not consistent. The best conclusion at this moment is to take $c_{h 2}=0.20$ for slopes of $1: 3$ and $1: 4$ and $c_{h 2 \%}=0.30$ for a slope of 1:6. Consequently, a slope of $1: 5$ would then by interpolation give $c_{h 2}=0.25$. This procedure is better than to use a formula like $c_{h 2 \%}=0.055$ cota, as given in EurOtop (2007). One can take $c_{\mathrm{u} 2 \%}=1.4-1.5$ for slopes between 1:3 and 1:6.

Moreover, the general form of equation 2 may even not be correct for run-up on a slope. Van der Meer (2011) analyzed individual waves rushing up the slope. Based on this analysis the following conclusion on the location of maximum or large velocities in the run-up of waves on the seaward slope of a smooth dike can be drawn, which is also shown graphically in Figure 4. In average the run-up starts at a level of $15 \%$ of the maximum run-up level, with a velocity close to the maximum velocity and this velocity is more or less constant until a level of $75 \%$ of the maximum run-up level. The real maximum velocity in average is reached between $30 \%-40 \%$ of the maximum run-up level. Figure 4 also shows that a square root function as assumed in Eq. 2 is not a correct assumption. The process of a breaking and impacting wave on the slope has influence on the run-up, it gives a kind of acceleration to the up-rushing water.

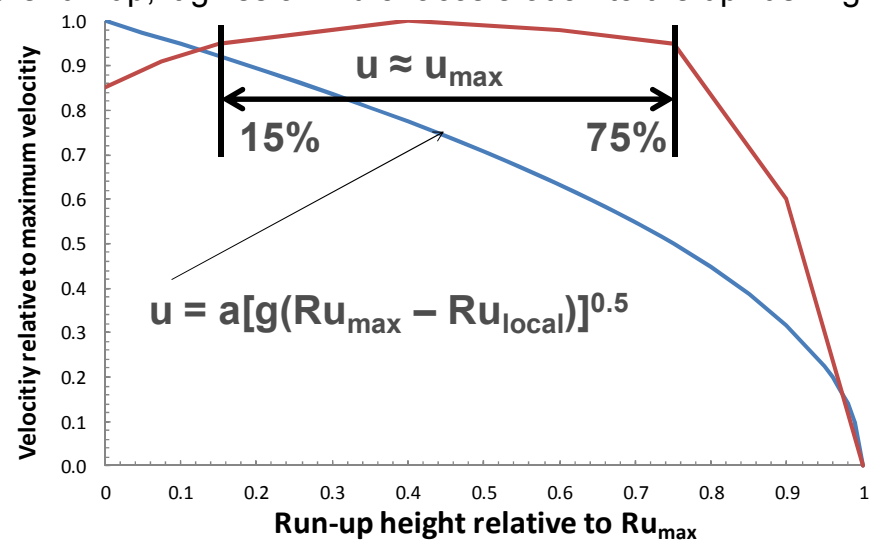

Figure 4. General trend of velocity over the slope during up-rush, compared to theory. 
Further analysis showed that there is a clear trend between the maximum velocity in each up-rushing wave and the (maximum) run-up level itself, although there is considerable scatter. Figure 5 shows the final overall figure (detailed analysis in Van der Meer (2011)), where velocity and maximum run-up level of each wave were made dimensionless. Note that only the largest velocities have been analysed and that the lower left corner of the graph in reality has a lot of data, but less significant with respect to effect on a grassed slope.

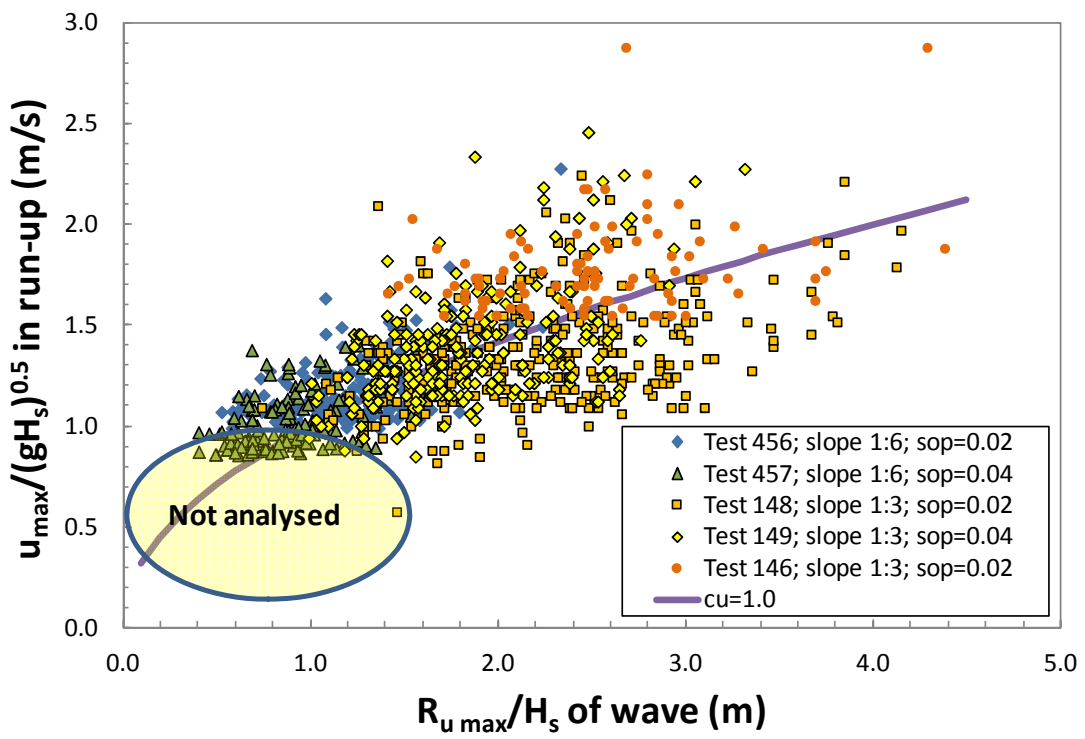

Figure 5. Relative maximum velocity versus relative run-up on the slope; all tests.

The trend and conclusion in Figure 4 explains for a part why the relationship between the maximum velocity and the maximum run-up in Figure 5 gives a lot of scatter. A velocity close to the maximum velocity is present over a large part of the slope and the actual location of the maximum velocity may be more or less "by accident". The trend given in Figure 5 can be described by:

$u_{\max } / \sqrt{\left(g H_{s}\right.}=c_{u} \sqrt{R u_{\max } / H_{s}}$

with $c_{u}$ as stochastic variable $\left(\mu\left(c_{u}\right)=1.0\right.$, a normal distribution with coefficient of variation CoV $\left.=0.25\right)$.

\section{Wave overtopping}

Like for wave run-up the EurOtop Manual (2007) gives the formulae for also for mean wave overtopping. This is the governing design parameter, which will not be repeated here. In reality there is no mean discharge, but several individual waves overtopping the structure, each with a certain overtopping volume, V. Recent improvements in describing wave overtopping processes have been described by Hughes et al. (2012). The distribution of individual overtopping wave volumes can well be represented by the two parameter Weibull probability distribution, given by the percent exceedance distribution in Eq. 5.

$P_{V \%}=P\left(V_{i} \geq V\right)=\exp \left[-\left(\frac{V}{a}\right)^{b}\right] \cdot(100 \%)$

where $P_{V}$ is the probability that an individual wave volume $\left(V_{i}\right)$ will be less than a specified volume $(V)$, and $\mathrm{P}_{\mathrm{V} \%}$ is the percentage of wave volumes that will exceed the specified volume (V). The two parameters of the Weibull distribution are the non-dimensional shape factor, $b$, that helps define the extreme tail of the distribution and the dimensional scale factor, a, that normalizes the distribution. 
$a=\left(\frac{1}{\Gamma\left(1+\frac{1}{b}\right)}\right)\left(\frac{q T_{m}}{P_{o v}}\right)$

where $\Gamma$ is the mathematical gamma function.

Hughes et al. (2012) give for b the following relationship (Fig. 6):

$b=\left[\exp \left(-0.6 \frac{R_{c}}{H_{m 0}}\right)\right]^{1.8}+0.64$

Figure 6 shows that for $R_{c} / H_{m 0}>1.5$ the average value of $b$ is about 0.75 and this value has long been used to describe overtopping of individual wave volumes (as given in EurOtop, 2007). But the graph shows that with smaller crest freeboard the b-value may increase significantly, leading to a gentler distribution of overtopping wave volumes. This new knowledge may have effect on designing and using wave overtopping simulators. Most recent work on the b-value is given in Zanuttigh et al., 2013.

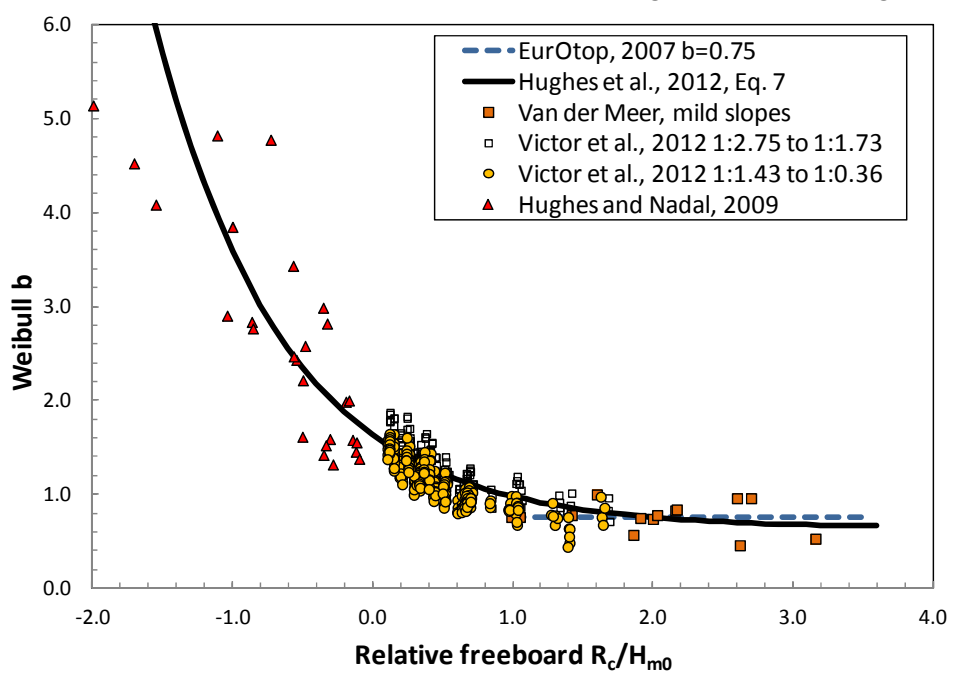

Figure 6. New Weibull shape factor, b, spanning a large range of relative freeboards (Hughes et al., 2012). Most recent information in Zantuttigh et al., 2013.

\section{Simulators as hydraulic test facilities}

\section{General aspects}

In total three types of Simulators have been developed, on impacts, run-up and on overtopping. The principle is similar for all three types: a box with a certain geometry is constantly filled with water by a (large) pump. The box is equipped with one or more valves to hold and release the water and has a specifically designed outflow device to guide the water in a correct way to the slope of the dike. By changing the released volume of water from the box one can vary the wave-structure interaction properties.

\section{Wave impacts}

The Wave Impact Generator is the most recent development under the WTI 2017-program of the Dutch Rijkswaterstaat and Deltares, see Figure 7. This tool is called a generator and not a simulator. It has been developed late 2011 and in 2012 and testing has been performed the first and second half of 2012. It is a box of $0.4 \mathrm{~m}$ wide, $2 \mathrm{~m}$ long and can be up to $2 \mathrm{~m}$ high (modular system). It has a very advanced system of two flap valves of only $0.2 \mathrm{~m}$ wide, which open in a split second and which enables the water to reach the slope at almost the same moment over the full width of $0.4 \mathrm{~m}$ and thus creating a nice impact. Measured impacts are given in Figure 2 and compared with impacts measured in the Delta Flume.

As the location of impacts varies on the slope, the Wave Impact Generator has been attached to a tractor 
or excavator, which moves the simulator a little up and down the slope. In this way the impacts do not occur all at the same location. Development and description of first tests have been described by Van Steeg (2012a, 2012b and 2013)

The main application is simulation of wave impacts on grassed slopes of dikes, like for river dikes, where the wave heights are limited to $H_{s}=0.5-1 \mathrm{~m}$. The impact pressures to be simulated are given by Eq. 1 , but within the range of wave heights given here. The impact pressure can be regulated by the empirically determined formula:

$p_{\max }=1.10 h_{w}+0.87$

where $h_{w}$ is the water column in the box, with $p_{\max }$ measured in $m$ water column. This relation has been calibrated for $0.25 \mathrm{~m}<\mathrm{h}_{\mathrm{w}}<1.00 \mathrm{~m}$. In fact only the largest $30 \%$ of the wave impacts is simulated, see also Figure 2.

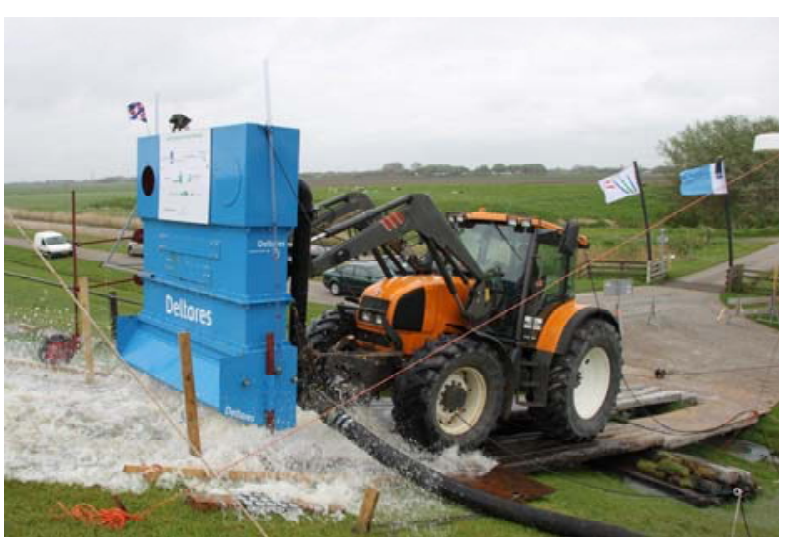

Figure 7. Test with Wave Impact Generator.

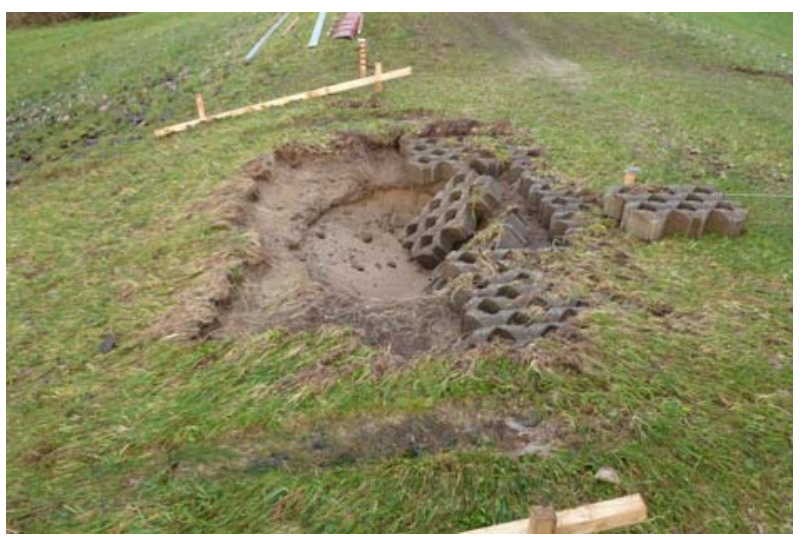

Figure 8. Failed road crossing by undermining due to simulated wave impacts.

Slopes with various quality of grass as well as soil (clay and sand) have been tested as well as a number of transitions, which are often found in dikes and which in many cases fail faster than a grassed slope. Figure 8 gives an impression of a road crossing of open tiles, which failed by undermining due to simulated wave impacts.

\section{Wave run-up and run-down}

A Wave Run-up Simulator has not yet specifically been developed. The process of run-up was explored, see earlier in this paper, as well as a procedure for testing was developed (Van der Meer (2011) and Van der Meer et al. (2012). Then a pilot test was performed on wave run-up simulation, but using the existing Wave Overtopping Simulator as an existing tool (description in the next section). The Simulator was placed on a seaward berm and run-up levels were calibrated with released wave volumes and these were used for steering the process. In this way the largest run-up levels of a hypothetical storm and storm surge, which would reach the upper slope above the seaward berm, were simulated. Figure 9 gives the set-up of the pilot test and shows a wave run-up that even reached the crest, more than $3 \mathrm{~m}$ higher than the level of the Simulator.

The pilot test gave valuable information on how testing in future could be improved, but also how a real Wave Run-up Simulator should look like. First of all the side walls should be stabilized as up-rushing water comes down again, creating significant pressures on these side walls. The pilot test also showed that a Wave Run-up Simulator should have a slender shape, different from the present Wave Overtopping Simulator. It should be a box $0.4 \mathrm{~m}$ to $0.6 \mathrm{~m}$ wide, fairly high and over a width of $2 \mathrm{~m}$ to $4 \mathrm{~m}$. With a different outflow guiding the present Wave Impact Generator could be used, but also a larger box could be developed with the correct outflow guidances and release valves. 
An example on damage developed by simulating wave run-up is shown in Figure 10. The up-rushing waves meet the upper slope of the dike and "eat" into it.

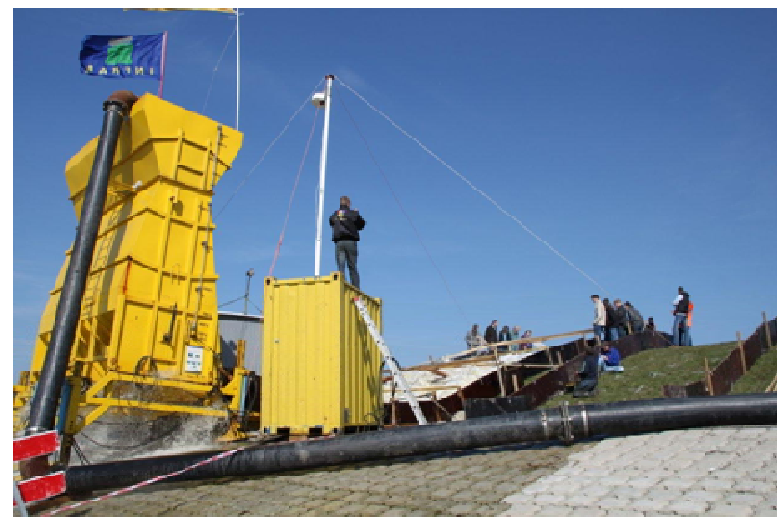

Figure 9. Set-up of the pilot wave run-up test at Tholen, using the existing Wave Overtopping Simulator.

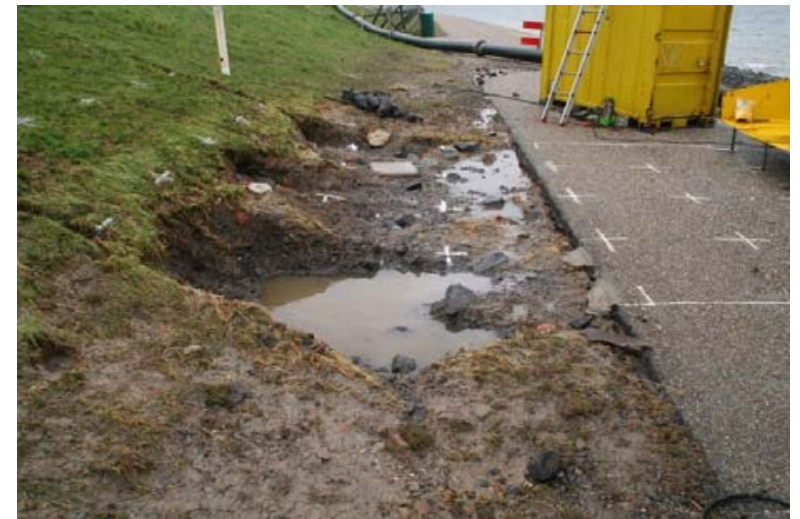

Figure 10. Final damage after the pilot run-up test.

\section{Wave overtopping}

The Wave Overtopping Simulator has been designed and constructed in 2006 and has been used since then for destructive tests on dike crest and landward slopes of dikes or levees under loading of overtopping waves. References are Van der Meer et al. (2006, 2007, 2008, 2009, 2010, 2011, 2012), Akkerman et al. (2007), Steendam et al. (2008, 2010, 2011) and Hoffmans et al. (2008), including development of Overtopping Simulators in Vietnam (Le Hai Trung et al. (2010)) and in the USA (Van der Meer et al. (2011) and Thornton et al. (2011)).

The setup of the Overtopping Simulator on a dike or levee is given in Figure 11, where the Simulator itself has been placed on the seaward slope and it releases the overtopping wave volume on the crest, which is then guided down the landward side of the dike. Water is pumped into a box and released now and then through a butterfly valve, simulating an overtopping wave volume. Electrical and hydraulic power packs enable pumping and opening and closing of the valve. A measuring cabin has been placed close to the test section. The Simulator is $4 \mathrm{~m}$ wide and has a maximum capacity of $22 \mathrm{~m}^{2}$, or $5.5 \mathrm{~m}^{3}$ per $\mathrm{m}$ width. The Simulator in Vietnam has the same capacity, but the Simulator in the US has a capacity of $16 \mathrm{~m}^{3}$ per m width (although over a width of $1.8 \mathrm{~m}$ instead of $4 \mathrm{~m}$ ). Released volumes in a certain time are according to theoretical distributions of overtopping wave volumes, as described in this paper, depending on assumed wave conditions at the sea side and assumed crest freeboard.

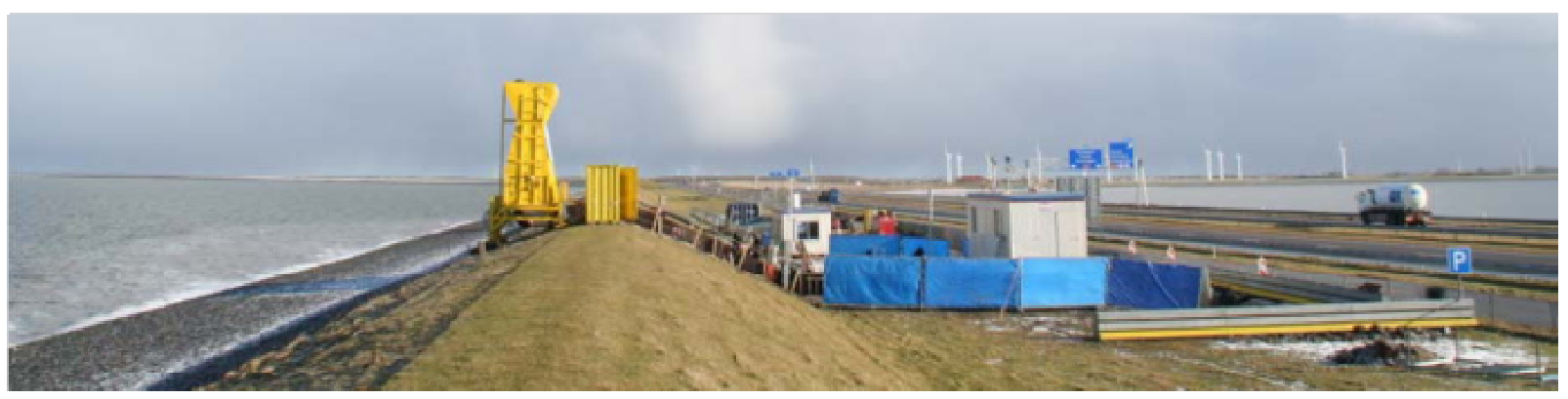

Figure 11. Set-up of the Wave Overtopping Simulator close to a highway.

Figure 12 shows the release of a large overtopping wave volume and Figure 13 shows one of the many examples of a failed dike section, here a sand dike covered with good quality grass. 


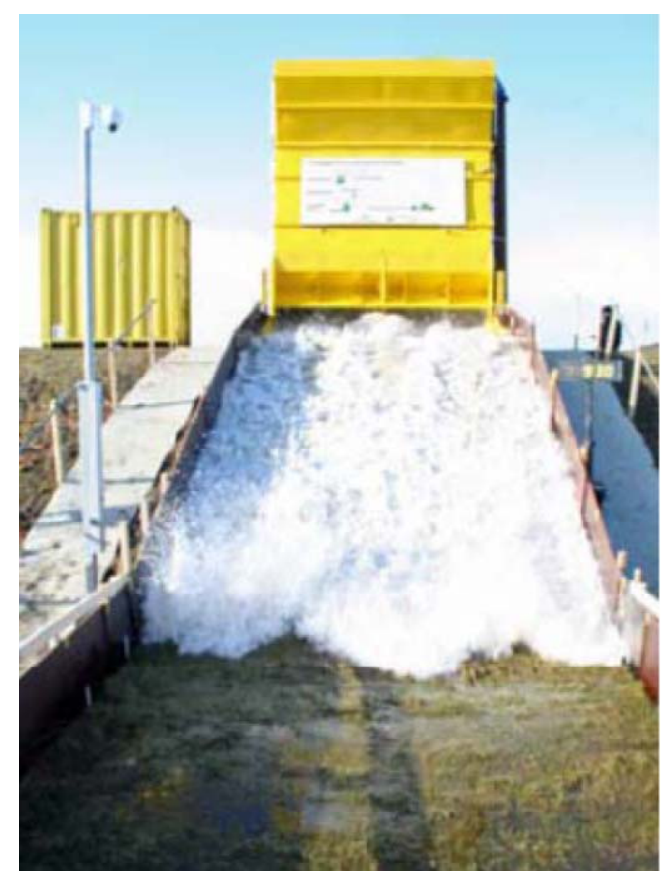

Figure 12. Release of a large wave volume.

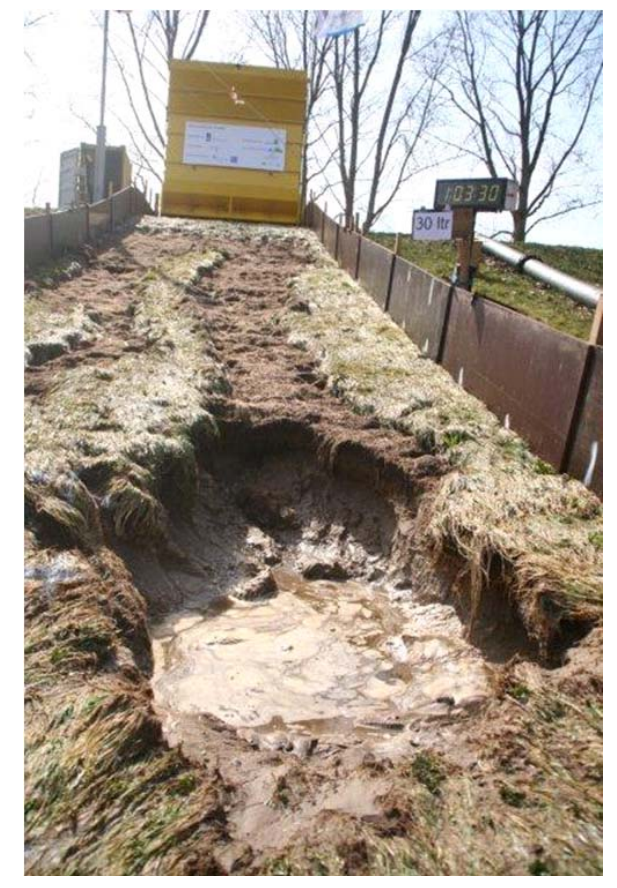

Figure 13. Failure of a sand dike.

\section{Summary and discussion}

Erosion of grassed slopes by wave attack is not easy to investigate as one has to work at real scale, due to the fact that the strength of clay with grass roots cannot be scaled down. There are two ways to perform tests on real scale: bring (pieces of) the dike to a large scale facility that can produce significant wave heights of at least $1 \mathrm{~m}$, or bring (simulated) wave attack to a real dike. For investigation in a large scale facility the main advantage will be that the waves are generated well and consequently also the wavestructure-interaction processes are generated well. The disadvantage is that the modelled dike has to be taken from a real dike in undisturbed pieces. This is difficult and expensive and real situations on a dike, like staircases, fences and trees are almost impossible to replicate. This type of research is often focussed on the grass cover with under laying clay layer only.

The second alternative of Simulators at a dike has the significant advantage that real and undisturbed situations can be investigated. The research on wave overtopping has already given the main conclusion that it is not the grass cover itself that will lead to failure of a dike by overtopping, but an obstacle (tree; pole; staircase) or transition (dike crossing; from slope to toe or berm). The main disadvantage of using Simulators is that only a part of the wave-structure-interaction can be simulated and the quality of this simulation depends on the knowledge of the process to simulate and the capabilities of the device. The experience of testing with the three Simulators, on wave impacts, wave run-up and wave overtopping, gave in only seven years a tremendous increase in knowledge of dike strength and resulted in predictive models for safety assessment or design.

\section{Acknowledgments}

Development and research was commissioned by a number of clients, such as the Dutch Rijkswaterstaat, Centre for Water Management, the Flemish Government, the USACE and local Water Boards. The research was performed by a consortium of partners and was mostly led by Deltares. Consortium partners were Deltares (project leader, geotechnical issues, model descriptions, hydraulic measurements, performance of wave impact generator), Infram (logistic operation of testing), Alterra (grass issues), Royal Haskoning (consulting), Van der Meer Consulting (performance of Simulators and hydraulic measurements) and Van der Meer Innovations (mechanical design of the Simulators). 


\section{References}

Akkerman, G.J., P. Bernardini, J.W. van der Meer, H. Verheij and A. van Hoven (2007). Field tests on sea defences subject to wave overtopping. Proc. Coastal Structures, Venice, Italy.

EurOtop (2007). European Manual for the Assessment of Wave Overtopping. Pullen, T. Allsop, N.W.H. Bruce, T., Kortenhaus, A., Schüttrumpf, H. and Van der Meer, J.W. www.overtopping-manual.com.

Hoffmans, G., G.J. Akkerman, H. Verheij, A. van Hoven and J.W. van der Meer (2008). The erodibility of grassed inner dike slopes against wave overtopping. ASCE, Proc. ICCE 2008, Hamburg, 3224-3236.

Hughes, S, C. Thornton, J.W. van der Meer and B. Scholl (2012). Improvements in describing wave overtopping processes. ASCE, Proc. ICCE 2012, Santander, Spain.

Klein Breteler, M., van der Werf, I., Wenneker, I., (2012), Kwantificering golfbelasting en invloed lange golven. In Dutch. (Quantification of wave loads and influence of long waves), Deltares report H4421, 1204727, March 2012

Le Hai Trung, J.W. van der Meer, G.J. Schiereck, Vu Minh Cath and G. van der Meer. 2010. Wave Overtopping Simulator Tests in Vietnam. ASCE, Proc. ICCE 2010, Shanghai.

Schüttrumpf, H.F.R. 2001. Wellenüberlaufströmung bei See-deichen, Ph.D.-th. Techn. Un. Braunschweig.

Steendam, G.J., W. de Vries, J.W. van der Meer, A. van Hoven, G. de Raat and J.Y. Frissel. 2008. Influence of management and maintenance on erosive impact of wave overtopping on grass covered slopes of dikes; Tests. Proc. FloodRisk, Oxford, UK. Flood Risk Management: Research and Practice - Samuels et al. (eds.) ISBN 978-0-415-48507-4; pp 523-533.

Steendam, G.J., J.W. van der Meer, B. Hardeman and A. van Hoven. 2010. Destructive wave overtopping tests on grass covered landward slopes of dikes and transitions to berms. ASCE, Proc. ICCE 2010.

Steendam, G.J., P. Peeters., J.W. van der Meer, K. Van Doorslaer, and K. Trouw. 2011. Destructive wave overtopping tests on Flemish dikes. ASCE, Proc. Coastal Structures 2011, Yokohama, Japan.

Thornton, C., J.W. van der Meer and S.A. Hughes. 2011. Testing levee slope resiliency at the new Colorado State University Wave Overtopping Test Facility. Proc. Coastal Structures 2011, Japan.

Van der Meer, J.W., P. Bernardini, W. Snijders and H.J. Regeling. 2006. The wave overtopping simulator. ASCE, ICCE 2006, San Diego, pp. 4654 - 4666.

Van der Meer, J.W., P. Bernardini, G.J. Steendam, G.J. Akkerman and G.J.C.M. Hoffmans. 2007. The wave overtopping simulator in action. Proc. Coastal Structures, Venice, Italy.

Van der Meer, J.W., G.J. Steendam, G. de Raat and P. Bernardini. 2008. Further developments on the wave overtopping simulator. ASCE, Proc. ICCE 2008, Hamburg, 2957-2969.

Van der Meer, J.W., R. Schrijver, B. Hardeman, A. van Hoven, H. Verheij and G.J. Steendam. 2009. Guidance on erosion resistance of inner slopes of dikes from three years of testing with the Wave Overtopping Simulator. Proc. ICE, Coasts, Marine Structures and Breakwaters 2009, Edinburgh, UK.

Van der Meer, J.W., B. Hardeman, G.J. Steendam, H. Schttrumpf and H. Verheij. 2010. Flow depths and velocities at crest and inner slope of a dike, in theory and with the Wave Overtopping Simulator. ASCE, Proc. ICCE 2010, Shanghai.

Van der Meer, J.W., C. Thornton and S. Hughes. 2011. Design and operation of the US Wave Overtopping Simulator. ASCE, Proc. Coastal Structures 2011, Yokohama, Japan.

Van der Meer, J.W. 2011. The Wave Run-up Simulator. Idea, necessity, theoretical background and design. Van der Meer Consulting Report vdm11355.

Van der Meer, J.W., Y. Provoost and G.J. Steendam (2012). The wave run-up simulator, theory and first pilot test. ASCE, Proc. ICCE 2012, Santander, Spain.

Van Steeg, P., (2012a). Reststerkte van gras op rivierdijken bij golfbelasting. SBW onderzoek. Fase 1a: Ontwikkeling golfklapgenerator. In Dutch (Residual strength of grass on river dikes under wave attack. SBW research Phase 1a: Development wave impact generator). Deltares report 1206012-012-012HYE-0002, April 2012

Van Steeg, P., (2012b). Residual strength of grass on river dikes under wave attack. SBW research Phase 1b: Development of improved wave impact generator. Deltares report 1206012-012-012-HYE0015 August 2012

Van Steeg, P., (2013) Residual strength of grass on river dikes under wave attack. SBW research Phase 1c: Evaluation of wave impact generator and measurements based on prototype testing on the Sedyk near Oosterbierum. Deltares report 1207811-008.

Zanuttigh, B., J.W. van der Meer and T. Bruce, 2013. Statistical characterisation of extreme overtopping wave volumes. Proc. ICE, Coasts, Marine Structures and Breakwaters 2013, Edinburgh, UK. 